
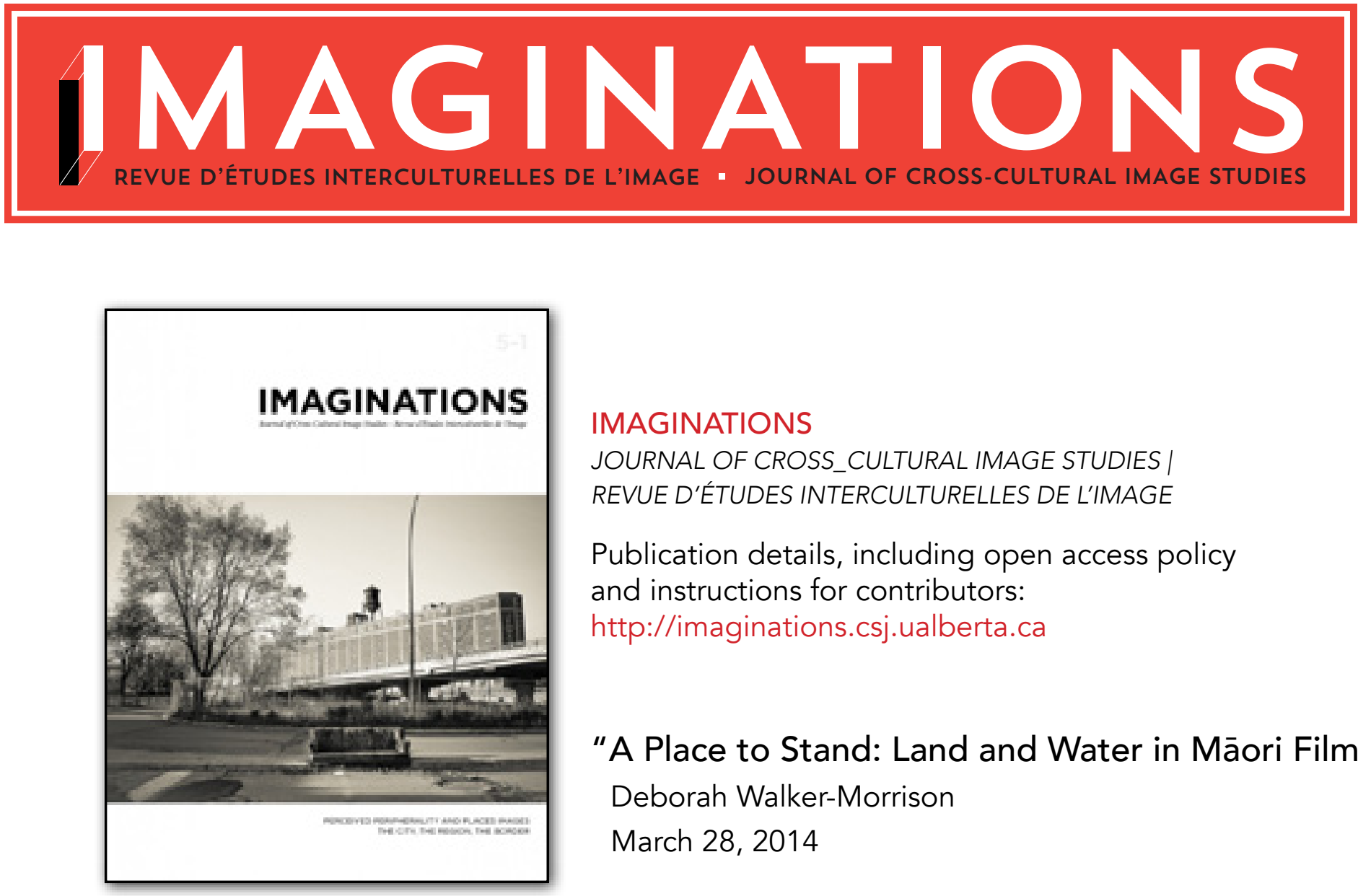

\title{
IMAGINATIONS
}

JOURNAL OF CROSS_CULTURAL IMAGE STUDIES |

REVUE D'ÉTUDES INTERCULTURELLES DE L'IMAGE

Publication details, including open access policy

and instructions for contributors:

http://imaginations.csj.ualberta.ca

"A Place to Stand: Land and Water in Māori Film"

Deborah Walker-Morrison

March 28, 2014

To Cite this Article:

Walker-Morrison, Deborah. "A Place to Stand: Land and Water in Māori Film" Imaginations 5:1 (2014): Web (date accessed) 25-47. DOI: 10.17742/IMAGE.periph.5-1.3

To Link to this article:

http://dx.doi.org/10.17742/IMAGE. periph.5-1.3

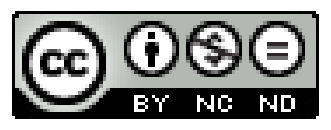

The copyright for each article belongs to the author and has been published in this journal under a Creative Commons Attribution NonCommercial NoDerivatives 3.0 license that allows others to share for non-commercial purposes the work with an acknowledgement of the work's authorship and initial publication in this journal. The content of this article represents the author's original work and any third-party content, either image or text, has been included under the Fair Dealing exception in the Canadian Copyright Act, or the author has provided the required publication permissions. 


\section{A PLACE TO STAND: LAND AND WATER IN MAORI FILM}

DEBORAH WALKER-MORRISON, UNIVERSITY OF AUCKLAND

New Zealand (NZ) Māori identity, as is the case for indigenous peoples the world over, is inextricably linked to a sense of place of origin, Türangawaewae, literally, "a place to stand one's feet." Place here is obviously first and foremost about land, but also includes the rivers, lakes and sea that have sustained Māori communities since their arrival in Aotearoa, almost a thousand years ago. Linking representations of land and water to a rereading of Paul Gilroy's twin metaphors of roots and routes, this paper reads issues of loss, conservation, regaining and/or transformation of such a sense of place as central to Māori fiction film.
L'identité Māori néo-zélandaise, à l'instar des autres peuples indigènes du monde, est inextricablement liée à un sens de lorigine géographique : Tūrangawaewae, littéralement "un endroit pour poser ses pieds." Le lieu spécifique domine ici la conception du territoire, mais cela n'exclut pas pour autant les rivières, les lacs et l'océan qui ont permis la survie du peuple Māori depuis son arrivée à Aotearoa, il y a près de mille ans. En rapprochant les représentations de la terre et de l'eau de la double métaphore des " routes " et des " racines ", cet article examine les questions de la perte, de la conservation, de la récupération et/ ou de la transformation en lien avec le sentiment du lieu en tant qu'il occupe une place centrale dans le cinéma de fiction Māori. 
As Māori we describe ourselves astangata whenua, "people of the land." When we introduce ourselves in an official setting, we begin with the name of our waka or canoe, one of the fleets of vessels that carried our ancestors on routes across the Pacific from Hawaiki (Raiatea, French Polynesia) to Aotearoa, around 1100 $\mathrm{AD}$, some seven hundred years before the arrival of the Pakeha.[1] We also give the name of our iwi (tribe(s)), hapu (subtribal grouping(s)) and details of our whakapapa (ancestry). But before naming people, we name our maunga and awa or moana, the mountain and river or lake that attach each hapu to a specific place, our geographical roots, our tūrangawaewae or "Place to Stand."[2]

The history of colonisation in this country, as elsewhere, has been largely a story of uprooting and dispossession. The nation's founding document, Te Tiriti ō Waitangi, signed in 1840 between representatives of the English Crown and $i w i$, while thought by Màori signatories to guarantee their peoples' sovereign rights and possession of taonga or resources (including land and water), was ignored for 150 years marked by armed conflict (the Land Wars 184572) and ongoing despoliation and loss (see R. Walker1990). Māori politics and arts, including literature and film, in this country, as elsewhere, have always been-inevitably-- "about" this central loss of geographical, socio-economic, cultural and spiritual roots. But they are also, more importantly, about regaining our "place," about routes of return and revival.

\section{Roots and Routes}

This article proposes that representations of land and water in Mãori cinema can be closely linked to the twin concepts of roots and routes proposed by Paul Gilroy (1993) in his groundbreaking study of transatlantic black identities and modernity. I use Gilroy's transnational, diasporic metaphor of routes, in an indigenous Māori context, as connected to the element of water and signifying cultural return, conceptual mobility, spirituality and individual or collective change. Where Gilroy uses the chronotope of the sailing ship to discuss the initial traumatic displacement and subsequent journeys of discovery of blacks across the Atlantic, I use that of the waka or canoe (which can also translate as vehicle/car) to reference the historical voyages of Māori ancestors across the Pacific to Aotearoa and contemporary voyages within and around the land. Secondly, for indigenous peoples such as Maori, colonization occupies a (loosely) similar position to that of slavery for Blacks in Gilroy's work and results in its own particular experiences of double consciousness (the generally painful, potentially empowering experience of living more than one racial and cultural identity). Thirdly, I read the metaphor of roots (which, in Gilroy, loosely signifies the distant original African homeland and its multiple traditions) as relating to the Màori relationship to the land we have inhabited for some 900 years, and to our resulting position as tangata whenua, people of the land, even or especially when this relationship has been and continues to be disrupted, via colonisation 
and its postcolonial aftershocks. It is important to note that in the films I discuss (in Mãori terms, as with other Pacific and indigenous peoples), paired elements such as land and water / roots and routes, appear to function somewhat differently to Western traditions, as complementary poles rather than as mutually exclusive opposites or Derridean binaries, with one term always already privileged over the other, both terms subsequently collapsing into one another. While the two can often be seen to merge, one element (land) or related set of terms and metaphors (roots, house, situated identity, life force) does not exclude, oppose, sit in a hierarchical relationship with, or collapse into the other (water, canoe, fluidity, voyage, transformation, renewal) (Walker-Morrison and Ramsay 237). Thus the discovery of new routes, new ways of being and doing, can lead to a re-discovery of roots, a reinvention of traditional identity and creation of a third space.

The following discussion outlines the interplay of these related concepts at work in a corpus of four fiction films, from the first Māori features of the 1980s (Ngāti, Barclay 1987; Mauri, Mita 1988) to the popular successes of the 1990s (Once were Warriors, Tamahori 1994) and following decade (Whale Rider, Caro 2002). My working definition of Māori cinema as cinema which tells Māori stories, written by Māori, using Māori actors, and/ or directors, producers and crew, thus includes features directed and made by Pakeha and/or European (co-) producers, however problematic the involvement of these cultural outsiders may be considered in some quarters.
No Place to Stand in Once were Warriors (Lee Tamahori \& Rewia Brown, 1994)

I begin with the fiction feature which really put Māori filmmaking on the local and international map: the biggest grossing film in NZ film history until Jackson's Lord of The Rings trilogy (2001-2003): director Lee Tamahori and scriptwriter Rewia Brown'sOnce Were Warriors, (1994) after Alan Duff's 1990 novel of the same name. Warriors screened at Cannes, won awards at local and international festivals, was met with widespread critical applause and made \$NZ25 million at the international box office.[3]

The film opens with a seven second static shot of an idyllic rural landscape: pasture lands, framed by snow-topped mountains, reflected in a calm, blue lake. The soundtrack is of a different age, murmuring voices and haunting, flutelike instrumentals. [4] A spectator viewing the scene for the first time in 2013, post Jackson's Tolkien adaptations, might almost expect to meet the odd wizard or a hobbit or two... But no, as Tamahori's camera pulls back, the scene is revealed to be a contemporary one; however, this is no pastoral paradise but a billboard illusion planted beside a screaming motorway and neighbouring suburban slum (see fig. 1a and 1b). Through this opening "shot," Tamahori clearly establishes the cruel contrast between the tourist myth (reinvigorated by Air New Zealand's recent re-branding of Aotearoa as Middle Earth) and the ugly realities of urban life for working-class Māori. [5] Moreover, the billboard advertises a fictitious power company, ENZ Power, 
whose name references the privatisations of state-owned assets, begun in the 1980s and recently renewed by the current newright government. Such policies have generally not led to economic prosperity for Māori, as the film graphically demonstrates.
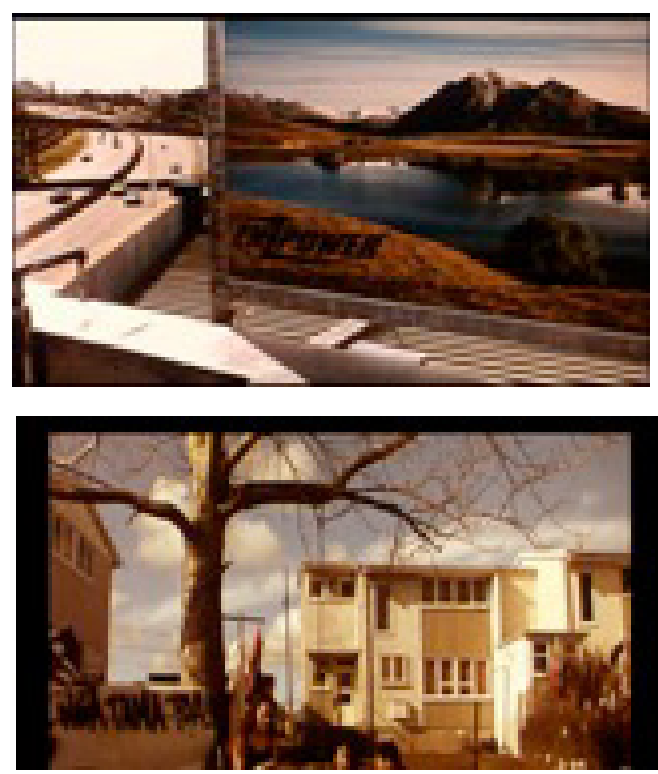

Fig. 1a A billboard illusion

Fig. 1b Urban living

The route to the Pakeha city has been no Yellow Brick Road. There is no land, no water, no place for urban Māori to stand in corporate NZ. During the ensuing expository prologue, a graffiti tagged on a wrecked car gives the name of the first modern Māori protest movement, $N g \bar{a}$ Tama Toa (The Young Warriors), which lobbied aggressively from the early 1970s for the return of Māori lands and the recognition and revival of Māori language and cultural institutions. In this context, the almost schizophrenic, sociopathic rage that inhabits the film's male protagonist, Jake "The Muss" (Temuera Morrison), reads unambiguously, as springing from a dysfunctional urban environment and concomitant loss of cultural values and identity.[6] Moreover, physical strength, the foundation of hegemonic Māori masculinity,[7] is no longer a valued commodity in the workplace under late capitalism, and Jake is unemployed. Unable to play the traditional masculine roles of protector and provider, cut off from his language, his culture, and his land, Jake has become "a slave to your fists, to the drink" as his battered but feisty wife, Beth (Rena Owen) retorts. Jake's moral impotence is further highlighted when his eldest son, Nig (Julian Arahanga), joins a gang and the second son, Boogie (Taungaroa Emile), is sent away to a remand home. In a pivotal scene, the family hires a car and goes on a day trip to visit Boogie, stopping on the way by a lake. In the distance, between land and water, Beth points out her family's marae (geographical locus of traditional community), her türangawaewae, bathed in a nostalgic, almost mythical haze. Mythical for the children, for whom the marae is an unvisited homeland, nostalgic for Beth. Not so for Jake: we learn that because he is of a lower, "slave" caste, Beth's family refused the marriage so the young couple eloped to the city and her children have never visited their mother's (and their) whenua tuturu. [8] Rigid adherence by older generations to certain traditional values (caste system) is thus a contributor to social dislocation. [9] The film downplays this element of Duff's novel;[10] in Rewia Brown's screenplay, it is economic marginalization, loss of cultural identity and separation from the land that pull the Heke family into a destructive, downward spiral of 
double-consciousness, dysfunction and delinquency. "Embodying the (debated) statistics of 'Māori socio-economic disparity"' (Chapple 2000), the family embarks on a path of destruction caused by poverty, unemployment, alcoholism, domestic violence, sexual abuse and gang activity" (Martens 10).[11] Moreover, the film rewrites and amplifies Duff's counterpoint theme of cultural renaissance, first and foremost in the character of Māori social worker Bennett (George Henare), whose "job" is to teach the audience--through Jake's wayward teenage son--how masculine energy may be channeled into non-threatening forms of controlled, ritualized "violence" through traditional cultural practice, i.e. taiaha and haka (Māori martial arts and dance).

The character of Bennett, who navigates easily between both worlds, enables Warriors to begin the process of positive return to traditional, communitybased roots, which will be taken up by Beth. But the film also demonstrates how tragically overdue is such a return for many Māori, since it is precipitated by Boogie's incarceration and the suicide of daughter Grace (Mamaengaroa Kerr-Bell), victim of sexual abuse by a trusted family member and close friend of her father's (Cliff Curtis). The family (minus Jake) returns to Beth's marae for Grace's tangi (funeral). Tamahori introduces the scene via a sound bridge of women's voices uttering a karanga (ritual women's chant, calling visitors onto a marae) over a medium close-up of Beth in her suburban statehouse kitchen, as if calling her back to her people. In a slow dissolve, Beth's face and upper body are momentarily superimposed on a low angle medium close-up of the carved guardian standing atop the wharenui (meeting house), thus re-establishing the connection between Beth and her birthplace and announcing her future role as guardian of her whänau (family). Silhouetted against a clear blue sky, the brightness of the image contrasts poignantly with the funeral scenes that follow (see fig. 2) as the camera tracks down to thewharenui, cuts to the massed mourners arriving with the casket, watching over Grace's body, performing a haka in her honor before her burial by the lakeside.

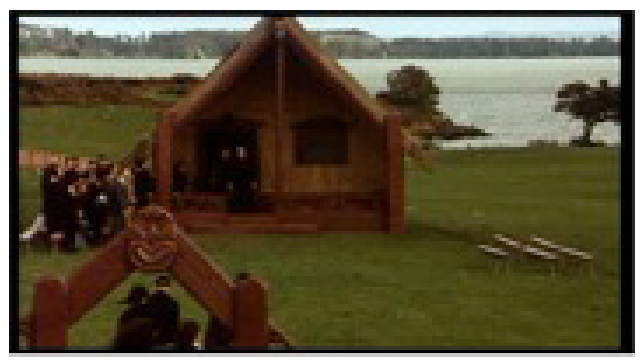

Fig. 2 Funeral scene

It is the return to this space, to her tùrangawaewae, that gives Beth the strength to leave her dysfunctional marriage and effect her own cultural rebirth, for herself and her children, declaring as the film ends: "Our people, once were warriors. They had mana, pride, People with spirit." The film remains important in many senses, in articulating the devastating consequences of dispossession but also, in that "Beth's pathway from victim to leadership reflects the passage of women taking leadership roles in the Mãori renaissance of the 1980s" (Joyce 163). 
Issues of central importance to the individual and community are always played out in relation to land and water as one's Place to Stand. The community is rooted in this very literal sense, but also a dimension of metaphorical fluidity is introduced through the element of water, closely linked to spirituality-the word wairua, "spirit" contains the word wai, "water." The central body of water may be a lake (Warriors) or river (e.g. River Queen, Vincent Ward, 2005) but because most films about Māori (whether directed by Māori or not) are set in coastal locations, water becomes most closely associated with the sea, as food / life source and as connection to ancestral and spiritual homelands.

\section{Fluid Spaces in Whale Rider, (Niki Caro, after Witi Ihimaera, 2002)}

Apart from Jackson's blockbuster Tolkien adaptations, Nicky Caro's screen interpretation of acclaimed Māori writer, Witi Ihimaera's (The) Whale Rider has been New Zealand cinema's most successful feature internationally since the turn of the millennium. Voted People's Choice at the Toronto International Film Festival, the film won 29 international awards and twelve year-old female lead, Keisha Castle-Hughes was nominated for an Oscar for Best Actress in 2002.

Set in the small, contemporary, Māori coastal community of Whangara (birthplace of Ihimaera and setting for the novel), the film tells how a young girl, Pai Apirana struggles to convince her Koro, grandfather and local chief (Rawiri Paratene, see fig. 3a and 3b), against centuries of patriarchal tradition, that she is the new leader he is seeking for his people. Pai knows she has been chosen for this role because of the strong connection she has with the whales which are her iwi's guardians (the first ancestor, Paikea, from whom she is a direct descendant, having arrived in Aotearoa, riding on the back of a whale). The dramatic climax sees a score of whales strand themselves on the local beach, while the community struggle in vain to save them. When all appears lost, Pai rides the leader of the pod back out to sea and the others follow.

As a film about roots (the centuries of communal experience and tradition that bind the community to the land) and routes (those that first carried the ancestors across the Pacific and those that carry their descendents away from and back to the land), Whale Rider mobilises key tropes in Māori film and literature. Caro's film follows Ihimaera's novel in advocating for the possibility of cultural revival while rejecting unquestioning adherence to tradition: the patriarchal division of labour in the form of exclusive male leadership and rights over traditional knowledge. Crucially also, both refuse a Manicheistic attitude towards their characters, inviting empathy or aroha for both the character of Pai, as a young girl having to assert herself against the patriarchal authority of the man she most loves and admires; and also for her Koro, as a leader who believes he is doing his best for his community. In the film, if Pai's voiceover narration privileges her position, shot reverse shot sequences emphasise reciprocity and dialogue, and Caro's use of point of view camera is extended to all the main characters, 
including Koro. Moreover, early scenes demonstrate a more endearing side to this stubborn patriarch: the old man's love for his granddaughter is revealed when we see him riding her home from school on the cross bar of his bicycle, laughing and joking with her, later responding to her curiosity about tribal history.[12]
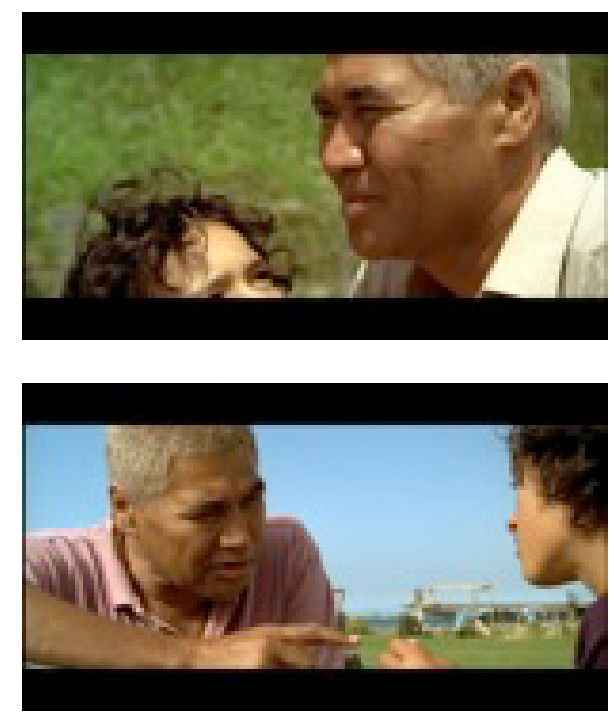

Figs. 3a \& 3b Rawiri Paratene, Pai’s Koro (grandfather)

Following the novel, Caro's camera constructs an intergenerational bond which Koro's conscious mind, in its obsessive search for a male heir, refuses for most of the film.

The film also suggests that it is Koro's intransigence that has driven away his elder son, Porourangi (Cliff Curtis). Unwilling to take on the traditional mantle of leadership for which his father has destined him, uprooted also by the death in childbirth of his wife and first son (Pai's twin), Porourangi (named after the "original" paramount chief of the eponymous iwi, Ngāti Porou, to which Ngāti Konohi belong) has left Aotearoa for Europe, to pursue his chosen profession as a sculptor. Indeed we learn that, like Māori artist Brett Graham who provided sculptures for the film and numerous others, the route to Europe has been a productive one, and Porourangi has established something of an international reputation for himself. Koro's scathing, traditionalist dismissal of his son's modernist inflected artwork as mere souvenirs serves to drive the two further apart. Moreover, the severing of Porourangi's connection to the land and the tribe's current lack of direction are given visual form in his half-finished waka, abandoned after the tragic circumstances surrounding Pai's birth. This plotline, an invention of the filmscript, enables Caro to set up the possibility of redemptive return: Pai's near-death experience prompting her father to complete the waka and (by extension) take up a key role in the community that is in tune with his own aspirations and talent.

Koro's younger son, Rawiri, is similarly seen to have been driven away by his father's single-minded obsession to find a male successor: as second son, his Māori martial arts talents remain unrecognized, and he has sunk into a lifestyle of drug and alcohol induced apathy. Thus, despite never having left the community, in a spiritual sense he has become cut off from his roots, through a combination of unemployment and filial disaffection. It is by becoming a mentor to Pai and by leading the community in their attempt to rescue the stranded whales that he will regain his place to stand. 
As many commentators (e.g. Gauthier, Gonick, Message, Morris) have noted, the film is firmly rooted in its Māori community, with many scenes situated in the communal spaces of marae, wharenui (meeting house) and wharekai (dining hall). In keeping with the exploration of the tensions between tradition (roots) and change (routes), both spaces are the setting for customary, community-based ways of being and doing (local school concerts, communal meals, Koro's revival of traditional martial arts and chiefly knowledge) and the questioning of tradition (Pai's refusal to sit at the back of the marae atea (open space in front of the wharenui) because she is a girl[13]; her pursuit of forbidden knowledges and besting of Koro's favoured contender). It is significant that Pai's dramatic speech, which outlines her own and her community's collective past and her democratic vision for its future ("We can learn that if the knowledge is given to everyone, we can have lots of leaders and soon everyone will be strong. Not just the one being chosen"), will be delivered (in traditional dress) in the space of the wharenui (Gonnick 314), thus revealing the latter's pivotal role as both traditional and transformational space.

Emphasising also the transformational role of water, the film stages the key test of the young boys Koro has chosen as contenders to succeed him at sea. Addressing the boys with a local proverb, Koro declares: "He rei ngā niho, he parāoa ngà kauae," which translates as "if you want to wield the whale's tooth, you must first have the jaw of a whale": leadership requires great strength. Koro then tosses overboard the whale tooth pendant he wears as a symbol of his own leadership and connection to the ancestral Whale Rider, Paikea. After the boys' failure to retrieve the taonga (treasure), Koro sinks into depression, following which it will, of course, be Pai who retrieves the tooth of the whale and who will demonstrate that she possesses the jawbone required to wield it.

The central drama plays out on the shore, where land and water meet. The stranding of the whales, spiritual guardians of the $i w i$, can be read as the result of, and a visual metaphor for the grandfather's intransigence. The fluidity of tradition is restored as the grandfather comes finally to accept the legitimacy of his granddaughter Pai's future leadership. This concept is embodied, firstly, in Pai's riding of the lead whale, who heads back out to sea, taking her on a journey which doubles that of her ancestor, before subsequently rendering her back to her people.

Secondly, the metaphor of water as movement and change is embodied in the final scene (not present in the book), as the iwi paddle out on a glittering sea, on Porourangi's beautifully restored waka "manned" by both men and women, towards a fluid future that has renewed its connection to its past (see fig. 4). As Cineaste reviewer Paula Morris notes, the final scene "suggests the beginning of a journey as great as the Pacific voyages of old. The purpose this time isn't to find new land, but to create a new world in the place where they live" (18). 


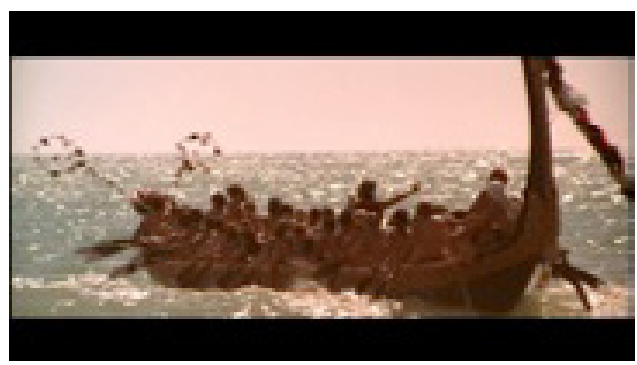

Fig. 4 Porourangi’s waka

The concept of water as a source of physical and intellectual mobility, spiritual connection and renewal, indeed as a kind of third space, takes on deep resonance here. While the film ends on an open question mark as to what type of economic enterprises will enable the people to move forward, a positive reading of its narrative resolution would argue that Pai's role in the return of the artist Porourangi, in the rehabilitation of his younger brother, Rawiri, in the opening of Koro to the possibility of change, and in the mobilisation of the entire community catalyzes multiple routes for $i w i$ to collectively navigate new routes between modernity and tradition. [14]

As well as the superb performance by its young female lead, the wild beauty of the film's coastal setting, its feel-good ending and astute visual story-telling (combining Māori ways of being with universal themes) made it a hit with audiences and critics, locally and internationally. Even sceptical Māori academic, Brendan Hokowhitu, had to admit that "indigenous people from around the world have embraced the film" (133). Still, echoing the reception of Warriors, the film provoked fierce debate. Veteran Māori filmmaker Barry Barclay (whose work and influence I will discuss presently), angered that the film had been directed and scripted by a Pakeha, made by a largely Pakeha crew, and co-produced with an eye to targeting international commercial markets, dismissed Whale Rider as "indigenous film for beginners" (in Calder A2). In my view, the judgment is overly harsh, particularly given the endorsement of Caro's work by Ihimaera (also executive co-producer), and given the enthusiastic involvement of highly respected Māori actors and the local community.[15] Nonetheless, one cannot but share Barclay's (and others') disappointment that the film was not made with greater involvement by Māori filmmakers. Moreover, the influence of the German co-producer on the story line is evident in the invention of a pregnant German girlfriend for Porourangi, who appears suddenly on the beach in the final sequence, as the waka is launched. Although she thankfully has no speaking part, her character, clearly designed to enable the German target audience to insert themselves into an uplifting story about indigenous eco-friendliness and cultural revival, detracts somewhat from the local authenticity of the story. [16] Reliance on foreign, first-world capital can have problematic implications for the integrity of local and indigenous filmmaking. Nonetheless, in spite of these shortcomings, it remains my view that Whale Rider constructs an experience which is not only respectful and worthy of its Māori source text, its culture and community, it is also an empowering one. As Marnina Gonick (and others) have argued, "...in adapting and blending traditional ways of knowing, generic cinema conventions and oral cultural sources, the film engages in a politics 
of re-imagination" (308), "effecting a decolonizing of the screen" (315). I would add that, through and beyond its feminist (re-) configuration of Māori agentic subjectivity, the film's mobilisation of the tropes of land and water, roots and routes, suggest productive ways in which iwi can negotiate a third space between tradition and modernity.

\section{The Roots of Māori Cinema: Merata Mita (1942-2010) and Barry Barclay (1944-2008)}

In the following sections, I want to suggest that Warriors, Whale Rider and other contemporary Māori films refer back, explicitly or implicitly to the roots of Māori cinema: the work of pioneer documentary filmmakers, teachers and cultural activists Merata Mita and Barry Barclay,[17] both one-time members of Ngā Tama Toa, who (co-) wrote and directed the first two Māori full-length fiction features. Shot more or less simultaneously, Ngāti (1987) and Mauri (1988) stand as major landmarks of the Māori cultural renaissance which began to gain momentum in the mid 1970s. Both films use similar geographical and temporal settings: small coastal communities in the post-war 1950s, the period which saw thousands of young Māori follow difficult routes, leaving their economically struggling rural birthplace to seek employment in the Pakeha towns. Both filmmakers use the medium of fiction film to document Māori realities, using Māori actors, settings, technicians, music and narrative methodologies, to "decolonize the screen" as Merata described it (Mita 49); inventing a philosophy of indigenous filmmaking which Barclay would term "Fourth Cinema" [18] and which would "show the way" for indigenous filmmakers the world over.

The title, Mauri, meaning life force, emphasizes the spiritual connection to land and water and the importance of birth place and ancestral connection to land in the establishment of identity. Türangwaewae, one's Place to Stand, is most often synonymous with one's place of birth (or the birthplace of one's tipuna or ancestors), one's whenua tūturu, originary or true home. The film embodies this kaupapa (theme) from its opening scenes of traditional birthing practice, which demands that the umbilical cord and placenta be returned to the earth, tying the child to its roots in the Land.

This ceremony is instigated and performed by the film's central character, kuia (grandmother or wise woman) Kara (Eva Rickard), who is bringing up her young granddaughter, Awatea (Rangimarie Delamare). Her family's land has been lost through a miscarriage of Pakeha justice and deviously purchased by her now senile Pakeha neighbour, Semmons (Geoff Murphy). The multiple narrative threads coalesce around the return of her son, Rewi (Anzac Wallace), after an absence of twenty years. Rewi provides support but Kara's attempts to persuade him to marry her beautiful niece, Ramiri (Susan Paul), are in vain. This is a troubled man with a dark secret. Not until the final act of the film is the mystery unveiled: he is an impostor and an escaped prisoner, Paki Hemapō, who stole the identity of Rewi 
Rāpana, when the latter was killed in a car accident while attempting to return home. On her deathbed, Kara instructs the now fugitive Paki to return to the scene of his "crime," where he disposed of Rewi's body, and seek forgiveness.

The film stages the theme of colonial land theft and restitution through characterisation and plot, dialogues, casting and mise en scène. Played by fellow director Geoff Murphy, Mita's long-time partner in life and art (also coproducer of Mauri), Semmons is a wildly and humorously exaggerated caricature, a point which has been lost on most Pakeha reviewers, even those who have been highly sympathetic to the film (Shepard 122). The construction of Semmons evokes Gilroy's reading of Frederick Douglass' inversion of Hegel's masterslave dialectic: "[it] is the slave rather than the master who emerges from Douglass's account possessed of 'consciousness that exists for itself, while the master becomes representative of a 'consciousness that is repressed within itself"' (60). While Semmons clearly embodies the crazed, repressed nature of white racism, greed and colonial land theft, the film attempts to circumvent over-generalizing of the character, firstly via humour, but more importantly, by making a point of not visiting the sins of the father(s) on the son. Au contraire, Steve Semmons (James Hayward), the opposite of his father in every way, is respectful of local Māori, falls in love with Ramiri, marries her and returns the land. Secondly, the casting of veteran activist Eva Rickard as Kara, fiercely nurturing mother figure of the community, already connects the character with the "land question." Merata underscores this in a long, fifty second, static shot-sequence of Awatea and Kara setting off for a tangi, during which Kara talks about her own imminent passing. The scene explicitly evokes Dame Whina Cooper's historic hikoi or Land March of 1975. Attracting more than 60,000 supporters and 5,000 walkers, who walked the length of the North Island to the Parliament Buildings in Wellington, "in a powerful and innovative way, the land march embodied Māori protest over ongoing land alienation" (Royal). The hikoi raised awareness of the injustice of colonial misappropriation of Māori lands and ushered in an ongoing process of restitution. The most enduring archival image of this historical event shows kuia Whina in the same position as Merata shoots Kara / Rickard, from behind, walking along a country road, supporting herself with a walking stick, hand in hand with a young child.

Land and water are intimately related to the spiritual cycle of life and death. Being cut off from the land thus signifies spiritual impoverishment. We see this in the character of Paki, whom Merata describes as an allegory or parable about "the schizophrenic existence of so many Māori in Pakeha society" (Mita 49). His attempted return is compromised because he has stolen another's identity: the price must be paid for his transgression, not so much of Pakeha law (attempted theft of money in a bank robbery gone wrong), but of Māori law: the theft of Rewi's "Place."[19]

The final sequence intercuts shots of Kara's dying moments, her funeral 
procession, her granddaughter running to a hilltop to wave her Nanny's spirit on its way, the expiation and surrender of the fugitive, Paki. It is no coincidence that Merata shot this latter scene at dawn, at the water's edge, place of spiritual cleansing. The protagonist is framed against a rock face: wrists crossed, eyes closed, chanting prayers, imploring the spirit of the dead man, the ancestors and living community he has wronged. As if in response, a sound bridge overlays the end of the first scene with the chanting of tribal leader, Hēmi (Sonny Waru), watching over the dying Kara with a group of loved ones. Intercutting continues until Paki completes his mission of rendering the dead man's possessions to the sea, upon which Kara expires and Awatea, who has been watching through a window, turns to run up the hill Kara has told her will be her route to the spirit world. When we cut back to Paki, the ensuing scene contains no dialogue, the soundtrack composed entirely of his sobbing and the gentle lapping of the cleansing sea around the rocks. As two Māori policemen arrive to take him into custody, the elder (Don Selwyn) approaches, takes his hands and the two hongi (press noses in the traditional Māori greeting), exchanging breath in a gesture of mutual recognition and respect. Unable to take Paki into custody himself, he leaves it to his younger colleague[20] to handcuff the prisoner's extended wrists. Cut to a medium close-up of Paki gazing skyward, holding his arms aloft until we hear the click of the cuffs like a prison door closing. This sound cues another abrupt cut, but not to a prison cell. Instead we see a kotuku (heron) in majestic flight against a clear blue sky, as if the bird has been summoned by this final act of supplication. The cut takes us from imprisonment to freedom, suggesting forgiveness and redemption for the troubled male protagonist.

The kotuku is traditionally considered to accompany the spirit of the dead (especially in the case of a chief or other respected community member) on its journey north, to the tip of the island, to Te Reinga, the leaping off place, from where it makes the long journey across the Pacific, to the originary homelands of Hawaiki nui, Hawaiki roa, Hawaiki Pāmāmao (Hawaiki the great, the long, the far-distant) and the Spirit World, Te $P \bar{o}$ (the Night). The scene then cuts back to Kara's tangi, the group of mourners solemnly crossing the paddocks, now filmed with an aerial camera, in a bird's eye / spirit-eye view. Meanwhile, the soundtrack is gradually filled with a soft lament, Maringiringi noa nga roimata / "Our tears flow unchecked," the words which Kara has previously recited to Paki and which are also the film's theme song. Aerial shots alternate with circular, closeframed, high angle shots of the young Awatea standing on the hilltop, tearfully gazing skywards towards us as she waves her grandmother's scarf in a final farewell (see fig. 5). 
A masterful combination of mise en scène, montage and subjective camera align the spectator with both the kotuku and the departed kuia. Graeme Cowley's sweeping, circular, aerial cinematography takes the spectator on the spirit journey over land and sea; flying northwards but looking back, ensuring and reaffirming that the mauri of the community lives on, symbolically invested in the young girl whose name, Awatea, means dawn.

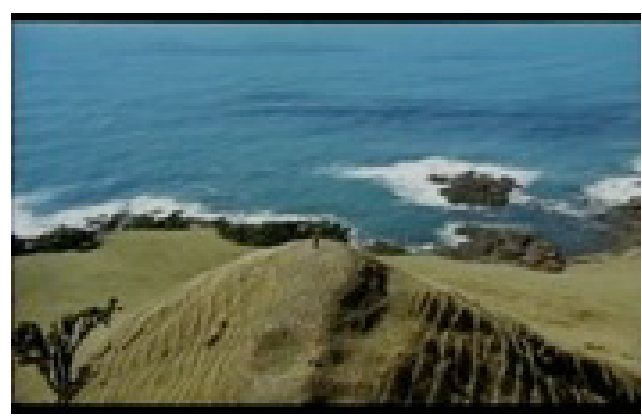

Fig. 5 Awatea upon the hilltop

We see Merata not simply drawing on the symbolism of the kotuku as spirit guide here, but imbuing it with multiple meanings which her subjective, winged camera, breathtaking land- and seascapes, and Hirini Melbourne's poignant, mounting musical score elevate to the level of what can only be described as the cinematic sublime (Freeland). Imprisonment and surrender become liberation, redemption; the pain of death, separation, tears of loss become spiritual journey, the route back to the originary homeland, while the mauri or life-force of the community, its rooted connection with the land, is renewed.

\section{Prophetic Places to Stand in Barry Barclay's Ngäti, 1987}

Barry Barclay's first fiction feature, Ngāti, 1987 , is "....widely credited as being the first fiction feature by a member of an Indigenous community" (Murray 1). Ngāti (tribe, people) is set in 1948, in post-war rural NZ, in a small (fictitious) coastal community similar to that of Mauri. The narrative's three interwoven plot strands enable the film to straddle several genres: romance, family melodrama, and what, in European terms, might be best described as neo-realist social drama. In the romance / melodrama plot line, a local born, Australian-raised doctor (Ross Girven) returns "home" for a holiday. The handsome but precocious young "Aussie" redneck is gently "re-educated" by the locals, before discovering that his biological mother was Mãori, then falling in love with the local (Pakeha) schoolteacher (Judy MacIntosh). The family melodrama centres on the illness of Rōpata (Oliver Jones), a young Māori boy dying of leukemia, and the failed attempts of the sympathetic Pakeha doctor (father of the school teacher, played by Norman Fletcher) and Māori tohunga (healer) to cure him. The social drama plot thread turns on an impending threat to the tightknit community when the Pakeha owners of the local freezing works (abattoir and meat processing plant) announce plans to close it down, effectively putting most of the town out of work.

As one would expect, Barclay's concept of indigenous Fourth Cinema is a deeply democratic "of the people, by the people, for the people" approach, driven by 
values of collaboration, community and reciprocity. It supposes syncretic, hybrid approaches to life and work which take a lead from holistic, community-focussed indigenous values and economic practice. Sympathetic, well-educated Pakeha characters in Ngäti (the local doctor and his family) who are happily integrated within the Māori community reflect Barclay's desire that Pakeha also have their Place to Stand, within "..a bi-cultural New Zealand that is fundamentally Māori in spirit" (Murray 62). This inclusive approach is suggested from the film's opening: Haere mai, a traditional welcome song, plays over shots of an old bus, wending its way into the town, welcoming the viewer along with its newly returned son. Moreover, the "return" of Aussie doctor, Greg, his discovery of his Māori ancestry and integration within the community can be read as a call, by Barclay, for a generation of mixed blood, urban Māori New Zealanders to rediscover their roots.

Both Mita and Barclay's films share an underlying documentary aspiration that seeks to record--almost as directcinema--the lived experience of indigenous communities, the ebb and flow of life and death, whether in documentary or fiction film. Thus, inNgāti as in Mauri, we are shown numerous scenes of (most often) communal activity (see fig. 6a and 6b): shearing, fleecing, stock-droving, fishing, gathering shellfish, eels, preparing food, singing, socialising, playing cards, eating, which serve no purpose in terms of driving the narrative, but are simply "about" the work of documenting community,[21] about "creating a visual tapestry reflecting the physical details of Māori communal life" (Barclay Our Own Image 67).[22]
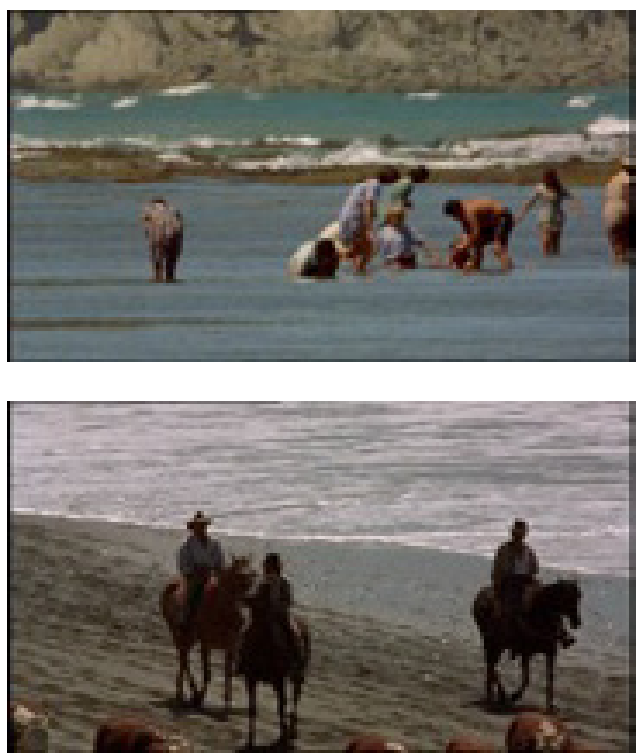

Figs. $6 \mathrm{a} \& 6 \mathrm{~b}$ Scenes of communal activity

Like Merata Mita and subsequent Māori filmmakers, Barclay's passionatelyheld belief in indigenous rights is inseparable from a deep commitment to inclusive cultural values, economic development and self-determination. This commitment, woven into every thread of their films, with more or less overt didacticism (and the term is not pejorative in the context of indigenous filmmaking and literature), is made particularly explicit within the social-realist drama plotline of Ngāti. As mentioned, the community is threatened with 'mass' unemployment by the impending closure of their local freezing works, which has become financially unviable, largely, we are told through the dialogues, because local Māori are imitating the big Pakeha farms and trucking their stock to a bigger plant further afield. As one stock drover explains: "I reckon our Māori 
communities don't know what they're doing any more. Pakeha send their stock to the works, Māori send their stock to the works. Pakeha go fishing, bugger me days, they all go fishing." Another adds: "It's the bloody money. And to top it all off, the bloody farmers, Màori and Pakeha, they have confidence in that works down south." We then learn that there is already little work left for the local drovers, since farmers are increasingly using trucks to transport their stock to "that works down south." In other words, the community's work and well-being, its ability to sustain itself via the land, is threatened by loss of faith in its own structures, coupled with the ill-considered adoption of individualistic, capitalist Pakeha business practice. A hui (meeting) is organised at the local marae (see fig. 7), with a couple of company representatives, who feign sadness at having to close the works before reminding the people how much they owe the company for having provided them with employment. A radical response and solution is proposed by the recently returned daughter of war veteran community leader, Iwi (Wì Kuki Kaa). Standing to address both the Pakeha company men and her people, Sally (Connie Pewhairangi) retorts: "I too would like to thank the company for providing employment. But the thanks shouldn't be one-sided. The company did not build its processing business here because it fell in love with the people. It built here so it could make big profits for its shareholders and directors. The company has enjoyed the sweat and labour of our people. Kapua did not need the company... Let us run our own freezing works. Our own farms, our own fisheries. Let us run them ourselves." The problem of dwindling stock numbers is solved by Sally's father, Iwi, who is the best stock manager in the region, greatly respected among both Māori and Pakeha, and who has just accepted the job of managing the biggest Pakeha-owned station, on his own terms. These are: total control over every aspect of the farm's management, including the power to decide to which freezing-works the stock will be sent. Supporting his daughter, "not because she is my daughter, but because what she says makes sense," Iwi declares: "...we will form an incorporation. We will buy the freezing works. We can and we will run it ourselves."

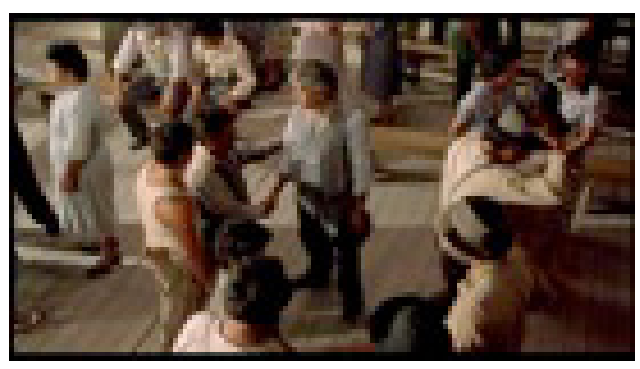

Fig. 7 Local marae (meeting)

Ngāti has been read as a nostalgic work, and in some ways perhaps it is. Not that this is a negative term for Māori, for whom it is common to say we "walk backwards into the future" i.e. with an eye on the past. More than a nostalgic work, however, $\mathrm{Ng} \bar{a} t i$ is also a prophetic one. Firstly, the character of Iwi displays an ability to find new routes, to bend the economic tools of modernity to the service of his community in ways which also nourish their roots: in this respect (as well as in its integration of Pakeha characters into the Māori world), the film constructs its rural community 
as forward-looking third space.

Secondly, Ngāti acts as a prescient sociopolitical document, made in the early years of an ongoing process of redress of historical colonial injustices, first and foremost among which is widescale theft of land and other resources. Since the film was made, this process has seen some of the resources that were misappropriated under colonialism returned to their original tribal "owners" (Māori prefer the term kaitiaki, which translates loosely as custodians). From 1990 - 2006, the Crown oversaw NZ\$900 million in financial settlements including the return of land and forestry, into the control of $i w i$. In 2007 , according to financial sources, $12 \%$ of the country's agricultural land was Māori owned. Commercial operations include farming, horticulture, viticulture, commercial forestry, gravel extraction and mining, property investments and the seafood industry. Since Ngāti, Māori have indeed formed many economically viable incorporations. Despite setbacks and inevitable disagreements, we have shown that we can "run things ourselves."

Barclay's view of cinema was a radical vision and one which is not shared by all Māori, whether filmmakers or industry stakeholders. The production values and aesthetics of Tamahori's Once were Warriors, Caro's Germancoproduced Whale Rider, and the younger Taika Waititi's playful, irreverent, and highly stylised popular comedies (Eagle vs Shark 2007, Boy 2010),[23] to name but a few examples, are a far cry from Barclay's more unpolished, non-commercially focussed insider-asceticism. Similarly, in terms of economic models for Mãori society outside of the film industry--how Māori would manage the freezing works and farms and fishing rights once they gained collective ownership over them-Barclay was to become critical of the corporate models often adopted by $i w i$ in order to manage their newly reacquired resources. There is still much healthy debate in Māoridom as to the ability of culturally foreign, capitalist business models and practices to deliver the best outcomes for Māori communities, whether in the so-called culture industries or elsewhere. But whatever one's views, within the context of these ongoing debates, Barclay's body of work as a whole, and Ngäti in particular, remains a powerful and positive encapsulation of Māori moves towards collective economic agency and responsibility.

Battles have been won, but the war is not over. In 2012, iwi attempts to purchase 16 large dairy farms (in receivership) were frustrated when the right-wing government allowed the lands to be sold to a Chinese business consortium. [24] In the same year, a Māori Council court action did not succeed in arresting plans by the same government to partially privatise state-owned hydroelectric companies which depend on the water from our rivers, recognised as taonga (Māori treasures or resources) under the Treaty of Waitangi. Māori are heavily involved in debates over land and water that are both current and ongoing. As historian Ranginui Walker states in the title of his 1990 alternative history of Aotearoa: Kā whāwhai tonu mātou, "We are still fighting." 
For sheer reasons of space, I am aware that I have not done anything like full justice to the films and concepts I have outlined here. This overview has nonetheless attempted to demonstrate the centrality of place (land and water) to Māori narrative filmmaking. More importantly, it has argued for the importance of Māori cinema in articulating the centrality of Land and Water to an evolving sense of individual and community identity, i.e. in (re-) constructing Aotearoa as our Place to Stand. My hope is that this paper might encourage readers to take a closer look.

\section{Acknowledgement}

I would like to thank the two anonymous referees whose astute comments and generous suggestions pushed me to broaden and strengthen my discussion. Na reira, ngā mihi nui ki $\bar{a}$ raua.

\section{Endnotes}

[1] Māori is the indigenous term (adjective and noun) pertaining to ourselves, the indigenous people of Aotearoa, New Zealand. Pakeha is the Māori term originally describing White settlers, now used more generally for Europeans.

[2] My iwi affiliations, on my father's side, are to the Rākai Pāka and Ngāti Pahuwera hapu of Ngāti Kāhungunu. Moumoukai is our maunga, Te Nuhaka is our awa, Te Manutai is our marae.

[3] Once were Warriors was notably well received in France. See Walker-Morrison 2011.
[4] The flute is the traditional kouauau, and the voices therefore demand to be read as those of the ancestors of the land, calling softly in a mournful, haunting lament.

[5] Tamahori has been criticised for subsequently reconstructing South Auckland's suburban geography with the alleged consequence of deforming or misrepresenting the social deprivation of his protagonists: "The dubbing or splicing of the physical environment in Once were warriors indicates a more serious deformation: the social criticism implied by the impoverished condition of this local culture is cloaked" (Turner 133). My subsequent discussion presents a counterargument.

[6] This causal link between unemployment and/or cultural dispossession and dysfunctional behaviours is central to Mauri (Mita, 1988) and forms a backdrop to Whale Rider (Caro 2002) and Boy (Waititi, 2010).

[7] Taika Waititi's recent films are a comic, gently critical exploration of contemporary Māori masculinity. His adult male protagonists are endearingly failed warriors who struggle to find their place to stand in the contemporary Pakeha (Eagle vs Shark, 2007) or Māori (Boy, 2010) world. In both films, Waititi comically restages contemporary masculine warrior training rituals (Eagle) or fantasy war games (Boy). In both films, scenes visualising this struggle take place in a beach setting, in the liminal space between land and water.

[8] Beth uses the term "taku whenua tuturu," my original or true land, of 
similar meaning to tūrangawaewae and which she glosses for her children as "my piece of dirt."

[9] This has been a major theme of Alan Duff's (otherwise powerful) writings, highly contestable and heavily criticized by Māori intellectuals as based more on personal opinion / grievance than statistical realities or sociological and historical research. See for example, R. Walker 1993 and Taylor.

[10] For a reading of the shifts between novel and film, see Renes.

[11] On its release, the film came in for much criticism, on the grounds that its glossy, "Hollywood" inspired aesthetics and uncompromising representations of domestic and gang violence served to (re-) produce non-historically contextualised, demonising stereotypes of Māori for local and international audiences (e.g. Pihama; Turner). Indeed, some academics still take the view that in popular films such as Warriors and Whale Rider, "colonialism is dehistoricised and depoliticised." See for example, Wilson. Nonetheless, other academic commentators came to recognise that "as an allegory, the film ceases to express the pathos and rage of the isolated individual and becomes the pretext for the revelation of colonised space, both historical and actual" (Simmons 339). Critical reception of Warriors thus shifted to include a more nuanced awareness of the ways in which the film inscribes the plight of its protagonists within a critique of colonialism, as "the dystopic outcome of white settlement in New Zealand" (Joyce
246). For a reasonably comprehensive review, see Martens.

[12] Brendan Hokowhitu's reading of Caro's construction of Koro (and Maori masculinity) as simply "despotic" (128) and "abhorrently patriarchal" (129), problematically overlooks these scenes. Moreover, the suggestion, in the same article, that key aspects of traditional Maori patriarchy fore-grounded by the film (most notably, male succession) are a colonial invention is not substantiated, either within the article or by historical evidence. To claim that contemporary Māori / indigenous identities have been inflected by the colonial experience is self-evident. To investigate specific ways in which this hybridization can be demonstrated, as Hokowhitu does (by looking at the influence of British-style private boys' schools on Māori masculinity) is important and merits further research. It does not follow however, that Māori patriarchy is therefore a colonial invention. See Hokowhitu.

[13] The question of women's rights to sit alongside men, to stand and speak within the open space of the marae atea was an issue of keen national debate around the time the film was made. Ngāti Porou were in fact one of the most liberal tribes in this respect, although their women still had to fight hard for the right to speak there (while, across the country, Māori women could and did speak within the wharenui). See Bidois.

[14] Critics of the film (e.g. Hokowhitu, notes 11 and 14), driven largely, it would appear, by its perceived hijacking by 
non-indigenous interests, also read Caro's failure to frame the story within a meta-narrative of colonial oppression as precluding a positive reading of its narrative resolution. Hester Joyce (Out from Nowhere) similarly argues that "The tragedy of Whale Rider is that the young woman seer, Pai, is saved and saves her tribe in a flight into fantasy that erases their past, rendering her people's deliverance hopeless" (248). The fact that such dystopian readings clearly do not reflect the film's reception by Māori and indigenous popular audiences (who were uplifted by the film's symbolic ending) is not taken into consideration.

[15] For further discussion, see Walker 2006.

[16] I would not go as far as Hokowhitu, for whom, "Menacingly, the hybrid child symbolizes the tribe's sealed destiny of becoming an indigenous component of global culture-like her father's creations in the visual arts. By blurring national and cultural boundaries, the infant's genealogical lines symbolize postindustrial, transnational agendas" (132). Worrying hints at miscegenation aside, Hokowhitu's equating of openness to the contemporary world with selling out to postindustrial, globalized capital effectively condemns Māori and other indigenous people to economic and cultural stagnation.

[17] Episode five in Barclay's landmark Tangata Whenua TV documentary series (1974) is entitled "A Place to Stand."
[18] Barclay 1990 and 2003. See also Stuart Murray's excellent monograph (2008).

[19] A similar theme of difficult return is explored in The Strength of Water 2009. Directed by Armagan Ballantyne after an original script by Māori playwright Briar Grace-Smith, the film was coproduced by Pandora Films, the same independent German company involved in Whale Rider, and the rural coastal setting and child protagonists invited many comparisons between the two films. There were no German characters this time, however. Presumably the German target audience were presumed less keen to insert themselves into this much darker narrative of damaged, mourning people and brooding landscapes. For a psychoanalytical reading, see Wild. The catalyst for the film's central drama (the accidental death of a ten year old girl and her twin brother's attempts to deal with his grief) is the arrival of a stranger, whose name, Tai, also means tide. Seeking refuge in his grandfather's abandoned house overlooking a wind-swept beach, Tai, like Paki, is a fugitive, a loner seeking and fearing connection, struggling to find his place in both the Pakeha world and the Māori world of his ancestors. As in Mauri, water symbolises passage, mourning, the connection to the spirit world, as evidenced by the cliff-top from where characters watch the swirling tide and talk about death, dying and other forms of leaving. Water is also the rain that threatens or falls almost constantly during the film, especially after Melody's tragic death: the life-giving force of water also has a darker strength. The film's theme 
song, Tihore mai te rangi, ("Clear up, sky": http://folksong.org.nz/tihore/) thus implores the rain to stop, lest life perish, and calls on the warming, life-giving force of the sun.

[20] Temuera Morrison in an early role, plays the unlikeable, upstart young cop.

[21] Gauthier argues that scenes of community life in Whale Rider are inspired by Barclay and Mita's indigenous approach (70).

[22] Barclay's intention to intercut shots of unscripted documentary scenes of the local people (many of whom played themselves in the film) into the fiction was sadly foiled by logistic and continuity problems.

[23] Merata Mita was co-producer on this film.

[24] After almost two years of legal battles and public debate, the purchase was settled on November 30, 2012. See Adams.

\section{Works Cited}

Adams, Christopher. "Crafar Farms Deal Finally Settled." NZ Herald OnLine (2012). 01.12. <http://www.nzherald. co.nz/business/news/article.cfm?c_ $\mathrm{id}=3 \&$ objectid $=10851202>$, Acc. $\mathrm{cc}$. 20.06.2013.

Barclay, Barry. "Celebrating Fourth Cinema.” Illusions 35 (2003): 7-11.

---. Our Own Image Auckland, N.Z.: Longman Paul, 1990.

Bidois, Vanessa. "Women on the Marae: Seen but not Heard?" NZ Herald On-Line (2000), 18.01. <http:// www.nzherald.co.nz/nz/news/article. cfm?c_id=1\&objectid=112121>. Acc. 20.06.2013.

Calder, Peter. "Riding High on 'Whale' Tale World Report: New Zealand Success of Whale Rider Promotes New Zealand Film Industry." Variety 393:5 (2003): A2.

Chapple, Simon. "Maori Socio-Economic Disparity." Political Science 5 (2000): 101115.

Freeland, Cynthia A. "The Sublime in Cinema." Passionate Views: Film, Cognition and Emotion. Eds. Carl Plantinga and Greg M. Smith. Baltimore: John Hopkins University Press, 1999. 6583.

Gauthier, Jennifer. "Indigeneous Feature Films: A New Hope for National Cinemas?" Cineaction 64 (2004): 63-71. $<$ http://www.thefreelibrary.com>

Gonick, Marnina. "Indigenizing girl power: The Whale Rider, Decolonization, and the Project of Remembering." Feminist Media Studies 10:3 (2010): 305-319.

Gilroy, Paul. The Black Atlantic: Modernity and Double Consciousness. Cambridge, Mass.: Harvard University Press, 1993.

Hokowhitu, Brendan. "The Death of Koro Paka." The Contemporary Pacific 20.1 (Spring 2008): 115-141. <http:// go.galegroup.com.ezproxy.auckland. ac.nz/ps/i.do?id=GALE\%7CA17290476 $0 \& v=2.1 \& u=$ learn\&it $=r \& p=A O N E \& s w$ $=\mathrm{w}$. $>$. Acc. 20.06.2013. 
Joyce, Hester. "Out from Nowhere: Pākehā Anxieties in Ngāti (Barclay 1978), Once Were Warriors (Tamahori 1994) and Whale Rider (Caro 2002)." Studies in Australasian Cinema_3:3 (2009): 239-250.

---. “Once Were Warriors." The Cinema of Australia and New Zealand. Eds. Mayer, Geoff and Keith Beattie. 24 frames. London: Wallflower Press, 2007. 157-64.

Martens, Emiel. "Maori on the Silver Screen: The Evolution of Indigenous Feature Filmmaking in Aotearoa/New Zealand." International Journal of Critical Indigenous Studies 5.1 (2012): 2-30. $<$ http://www.isrn.qut.edu.au/publications/ internationaljournal/documents/Final_ Martens_IJCIS.pdf> Acc. 20.06.2013.

Message, Kylie. "Whale Rider and the Politics of Location." Metro Magazine (2003): 86-90.

Mita, Merata. "The Soul and The Image." Film in Aotearoa New Zealand. Eds. Jonathan Dennis and Jan Bieringa. Wellington: Victoria University Press, 1992. 36-54.

Morris, Paula. "Review of Whale Rider, directed by Niki Caro." Cineaste 29:1 (2003): 18-19.

Murray, Stuart. Images of Dignity: Barry Barclay and Fourth Cinema. Wellington: Huia, 2008.

Pihama, Leonie. «Repositioning Maori Representation: Contextualising Once Were Warriors." Second Edition. Film in Aotearoa New Zealand. Eds. Jonathan Dennis and Jan Bieringa. Wellington: Victoria University Press, 1996. 191-194.
Renes, Conelis Martin. “Once were Warriors, But How About Maoritanga Now? Novel and Film as a Dialogic Third Space." miscelanea, a journal of english and american studies 44 (2011): 87-105. $<$ http://www.miscelaneajournal.net/index. $\mathrm{php} / \mathrm{misc} /$ article/download/67/38>囚. Acc. 20.06.2013.

Royal, Te Ahukaramū Charles. "Māori Urbanisation and Renaissance." On-Line Encyclopaedia of New Zealand. (2009): 5. <http://www.teara.govt.nz/en/Māori/5. > Acc. 20.06.2013.

Shepard, Deborah. Reframing Women: A History of New Zealand Film. Auckland: Harper Collins, 2000.

Simmons, Laurence. "Class and Ideology in Once Were Warriors." Southern Review 31:3 (1998): 330-42.

Taylor, Apirana. "Means Well, But... Review of Maori: The Crisis and the Challenge by Alan Duff." New Zealand Listener 10.07 1993: 50-1.

Turner, Stephen. 'Once were English.' Meanjin 58.2 (1999): 122-140.

Walker-Morrison, Deborah, and Rayene Ramsay. "Mon Whare, ton Faré: Building A Common House Through Translation in Pacific Literatures." Literatures of the Pacific Islands, Historical, Cultural and Comparative Perspectives._Eds. Jean Bessières and Sylvie André. Paris: Éditions Honoré Champion, 2013. 231-47.

Walker-Morrison, Deborah A. «Souls of Warriors': Once were Warriors in France." Te Kaharoa Vol. 1:1 Special Edition (2011): 18-33. <http://tekaharoa. com/index.php/tekaharoa/article/ view/88/55> Acc. 19.08.2013. 
Walker, Deborah. "Representing the Self, Representing the Other: The Ethics of Ethnic Representation." International Yearbook of Aesthetics 10 (2006): 99-106. $<$ http://www.iaaesthetics.org/publications/ yearbooks/> Acc. 20.06.2013.

Walker, Ranginui. "Eat Your Heart Out, Alan Duff. Review of Maori: The Crisis and the Challenge by Alan Duff." Metro July 1993: 136-37.

---. Ka whawhai tonu matou = Struggle without End. Rev. ed. Auckland: Penguin, 1990.

Wild, Harriet. "Creativity and Mourning in The Strength of Water." Illusions 43-44 (2012):13-18.

Wilson, Janet. «Re-presenting Indigeneity: Approaches to History in Some Recent New Zealand and Australian Films.» New Zealand Cinema: Interpreting the Past. Eds. Alistair Fox, Barry Keith Grant and Hilary Radner. Bristol, UK; Chicago: Intellect, 2011. 197-215.

\section{Image Notes}

Figs. 1a, 1b, 2 Once were Warriors, dir. Lee Tamahori \& scr. Rewia Brown, Communicado, 1994. (DVD: Magna Pacific 2009)

Figs. 3a, 3b, 4 Whale Rider, dir. Niki Caro, after Witi Ihimaera, South Pacific Pictures, 2002. (DVD: Buena Vista Home Video)

Figs. 5 Mauri, Merata Mita, Awatea Films, 1988. (DVD: Screenline 2010)

Figs. 6a, 6b, 7 Ngāti, Barry Barclay, Pacific Films, 1987. (DVD: Screenline 2009) 
Deborah Walker-Morrison is Senior Lecturer and Head of French at the University of Auckland, Aotearoa/New Zealand. Her principal research and teaching interests are in French cinema, Maori Cinema, and translation studies, with a particular focus on the translation of indigenous Pacific literatures. Of European and Maori descent, her kiwi affiliations are to the Rākai Pāka and Ngāti Pahuwera hapuof Ngāti Kāhungunu. As well as numerous articles and book chapters, she has published French and American Noir: Dark Crossings (Palgrave 2009, with Alistair Rolls) and Le style cinématographique $d>$ Alain Resnais (Edwin Mellen Press, 2012).
Deborah Walker-Morrison est Senior Lecturer et directrice du programe de français à l'Université d'Auckland en Aotearoa/Nouvelle-Zélande. Ses principaux intérêts de recherche son le cinéma français, le cinéma Maori, et les études de traduction (avec une concentration particulière sur la traduction des littératures indigènes du Pacifique. D’origine européenne et Maori, ses attaches à la Nouvelle-Zélande sont Rākai Pāka et le Ngāti Pahuwera hapu de Ngāti Kāhungunu. Outre de nombreux articles et chapitres de livre elle a fait publier French and American Noir: Dark Crossings (Palgrave 2009, avec Alistair Rolls) et Le style cinématographique d>Alain Resnais (Edwin Mellen Press, 2012).

This article is licensed under a Creative Commons 3.0 License although certain works referenced herein may be separately licensed, or the author has exercised their right to fair dealing under the Canadian Copyright Act.

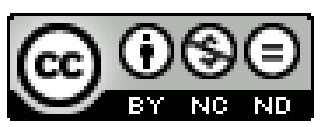

